\title{
Powder for Oral Solution in Sachet
}

National Cancer Institute

\section{Source}

National Cancer Institute. Powder for Oral Solution in Sachet. NCI Thesaurus. Code C149838.

Medicinal product consisting of a powder for oral solution presented in a sachet. 